\title{
Pengaruh Penambahan Tepung Kunyit (Curcuma longa) sebagai Pakan Tambahan Alami terhadap Efisiensi Pakan Sapi Peranakan Ongole
}

\author{
Novi Eka Wati ${ }^{1 *}$, Miki Suhadi ${ }^{1}$ \\ ${ }^{1}$ Program Studi Peternakan, Fakultas Peternakan, Universitas Tulang Bawang \\ *Corresponding author: novi.ekawati1990@gmail.com
}

\begin{abstract}
Abstrak
Tujuan dari penelitian adalah untuk mengetahui pengaruh penambahan tepung kunyit (Curcuma longa) dalam pakan terhadap efisiensi pakan Sapi Peranakan Ongole. Penelitian dilaksanakan di PGS. Joe Cipir Desa Jati Indah, Kecamatan Tanjung Bintang, Kabupaten Lampung Selatan. Penelitian menggunakan Rancangan Acak Kelompok dengan 9 ekor sapi peranakan Ongole jantan berumur $\pm 1,5$ tahun yang dikelompokkan menjadi 3 kelompok yaitu sapi dengan bobot badan $181,66 \pm 8,12 \mathrm{~kg}, 259,16 \pm 2,56 \mathrm{~kg}$, dan $355,83 \pm 8,12 \mathrm{~kg}$. Kandungan nutrien ransum kontrol adalah pakan yang biasa diberikan oleh peternak dengan kandungan protein kasar 8,82\% dan TDN $61,62 \%$. Perlakuan yang diberikan yaitu ransum kontrol $+0 \%$ tepung kunyit $(\mathrm{P} 0)$, ransum kontrol $+0,5 \%$ tepung kunyit $(\mathrm{P} 1)$ dan ransum kontrol $+1 \%$ tepung kunyit $(\mathrm{P} 2)$. Penelitian dilakukan selama 35 hari yaitu 7 hari periode adaptasi pakan dan 28 hari periode perlakuan. Hasil penelitian menunjukkan bahwa penambahan tepung kunyit hingga $1 \%$ pada pakan sapi memberikan pengaruh nyata $(\mathrm{P}<0,05)$ terhadap pertambahan bobot badan, efisiensi pakan dan feed cost pergain, namun tidak memberikan pengaruh nyata $(\mathrm{P}>0,05)$ terhadap konsumsi pakan harian. Kesimpulan yang dapat diambil penambahan tepung kunyit pada pakan hingga $1 \%$ bahan kering memberikan pengaruh positif terhadap pertambahan bobot badan, efisiensi pakan dan feed cost pergain sapi.
\end{abstract}

Kata kunci: Kunyit, Feed aditif alami, Sapi Peranakan Ongole, Efisiensi pakan, Feed Cost Pergain.

\begin{abstract}
The aim of the study was to know the effect of Curcuma longa as herbal feed additive in the ration on consumption, body weight gain, feed efficiency and feed feed cost pergain of Ongole cross cattle. The research was conducted at PGS Joe Cipir Jati Indah Village, Tanjung Bintang District, South Lampung Regency. The experimental used 9 male Ongole Cross Cattle wich is divided into 3 groups with an average body weight of the first group 181,66 $\pm 8,12 \mathrm{~kg}$, the second group $259,16 \pm 2,56 \mathrm{~kg}$, and the third group $355,83 \pm 8,12 \mathrm{~kg}$. The study used a randomized block design with 3 treatments and 3 groups based on body weight. The control ration is the usual ration was given by farmers every day which is containing $8.82 \%$ crude protein and $61,62 \%$ TDN. They were fed a complete feeding with control rations $+0 \%$ turmeric flour $(P 0)$, control ration $+0.5 \%$ turmeric flour (P1) and control ration $+3 \%$ turmeric flour (P2). The study was conducted for 5 weeks, 1 week period of adaptation and 4 weeks period of data collection. The results showed that the addition $1 \%$ of turmeric flour had a significant effect $(P<0.05)$ on body weight gain, feed efficiency and feed cost pergain, but not affected $(P>0,05)$ on daily consumption. The conclusion showed that Addition 1\% of turmeric flour of the total dry matter rations showed a positive effect on body weight gain, feed efficiency and feed cost pergain.
\end{abstract}

Keyword : Turmeric, Natural feed additive, Ongole cross cattle, Feed efficiency, Feed Cost Pergain. 
Prosiding Seminar Nasional Pembangunan dan Pendidikan Vokasi Pertanian

Politeknik Pembangunan Pertanian Manokwari, 14 November 2020

e ISSN : 2774-1982

\section{PENDAHULUAN}

Seiring dengan meningkatnya konsumsi daging sapi Nasional yang tidak diimbangi dengan produksi daging sehingga dipenuhi dengan daging impor. Konsumsi daging sapi nasional pada tahun 2018 sebesar 124,292 juta ton, sedangkan produksinya hanya sebesar 4,779 juta ton (Dirjen PKH Kementan, 2019). Peningkatan produktivitas sapi Peranakan Ongole dapat mendukung pemerintah dalam mengurangi impor daging. Sapi Peranakan Ongole merupakan salah satu bangsa sapi lokal yang yang yang banyak dipelihara oleh peternak rakyat karena daya adaptasi yang tinggi yaitu dataran rendah sampai dataran sedang, dan tahan terhadap penyakit tropis dan parasit (Menteri Pertanian Republik Indonesia, 2012)

Peningkatan produktivitas sapi salah satunya dengan penambahan feed aditif alami dalam ransum. Selain harganya yang terjangkau, residu yang dihasilkan dari penambahan aditif alami hampir tidak ada sehingga menghasilkan produk ternak yang sehat dan aman dikonsumsi oleh manusia. Feed aditif alami yang biasa digunakan untuk ternak diantaranya rimpang-rimpangan seperti jahe, temulawak, kunyit. Hasil penelitian Wati dan Yusuf (2019), penambahan temulawak pada ransum sapi Peranakan Simmental hinga dosis 3\% dari total bahan kering ransum menunjukkan pengaruh positif terhadap konsumsi bahan kering, pertambahan bobot badan harian dan konversi pakan. Wati dan Yusuf (2020) menambahkan bahwa penambahan tepung temulawak pada ransum sapi Peranakan Simmental sampai dosis 3\% dari total bahan kering ransum menunjukkan pengaruh positif terhadap efisiensi pakan dan feed cost per gain. Level dosis penambahan tepung temulawak dengan dosis $1,5 \%$ dari bahan kering pemberian ransum menunjukkan pertambahan bobot badan, efisiensi pakan dan feed cost per gain terbaik.

Kunyit (Curcuma longa) merupakan tanaman rimpang yang banyak dimanfaatkan manusia sebagai antibiotik, antivirus, antioksidan dan memperbaiki saluran pencernaan (Shan dan Iskandar, 2018). Kunyit memiliki kandungan atsiri berkisar 2,5-6\% dan kandungan kurkuminoid sebesar 3-5\%, sehingga bersifat anti oksidan dan memperbaiki pencernaan (Hartati, 2013). Kurkumin dalam kunyit dapat merangsang dinding kantong empedu mengeluarkan cairan empedu dan merangsang keluarnya getah pankreas yang mengandung enzim amylase, lipase dan protease yang berguna untuk meningkatkan pencernaan bahan pakan seperti karbohidrat, lemak, dan protein. Disamping itu minyak atsiri yang dikandung kunyit dapat mempercepat pengosongan isi lambung sehingga nafsu makan meningkat dan pertambahan bobot badan ternak meningkat. Penambahan tepung kunyit dalam pakan diharapkan dapat meningkatkan 
Prosiding Seminar Nasional Pembangunan dan Pendidikan Vokasi Pertanian

Politeknik Pembangunan Pertanian Manokwari, 14 November 2020

e ISSN : 2774-1982

efisiensi pakan dan menurunkan feed cost per gain agar keuntungan yang diperoleh peternak lebih tinggi. Hasil penelitian Budiari et al., (2020) menunjukkan bahwa pemberian tepung kunyit pada level 1,5\% dalam konsentrat sapi bali dapat meningkatkan pertambahan bobot badan, efisiensi ransum dan pendapatan peternak, sehingga layak untuk diterapkan.

\section{METODE}

Penelitian dilakukan di PGS. Joe Cipir Desa Jati Indah, Kecamatan Tanjung Bintang, Kabupaten Lampung Selatan. Metode penelitian yang digunakan adalah metode kuantitatif dengan Rancangan Acak Kelompok dengan 3 perlakuan dan 3 kelompok berdasarkan bobot badan sapi. Perlakuan yang diberikan adalah $\mathrm{P} 0=$ ransum kontrol $+0 \%$ tepung kunyit, $\mathrm{P} 1=$ ransum kontrol $+0,5 \%$ tepung kunyit dan $\mathrm{P} 2=$ ransum kontrol $+1 \%$ tepung kunyit.

Materi penelitian berupa 9 ekor sapi Peranakan Ongole jantan berumur \pm 2 tahun yang dikelompokkan menjadi 3 kelompok yaitu sapi dengan bobot badan 181,66 $\pm 8,12$ $\mathrm{kg}, 259,16 \pm 2,56 \mathrm{~kg}$, dan $355,83 \pm 8,12 \mathrm{~kg}$. Ransum kontrol merupakan ransum yang biasa diberikan oleh peternak setiap hari dengan kandungan protein kasar sebesar 8,82\% dan TDN $60,62 \%$. Formulasi ransum dan kandungan nutrien ransum kontrol tersaji dalam Tabel. 1.

Tabel 1. Kandungan Nutrien Ransum Kontrol

\begin{tabular}{llccc}
\hline \hline No. & Bahan Pakan & \% Bahan Pakan & Protein Ransum & TDN Ransum \\
\hline 1 & Janggel jagung & 18 & 1,53 & 10,64 \\
2 & Onggok & 19 & 0,55 & 11,53 \\
3 & Bungkil sawit & 20 & 2,91 & 12,35 \\
4 & Kulit Kedelai & 10 & 0,67 & 4,97 \\
5 & Dedak & 20 & 2,51 & 14,28 \\
6 & Tetes & 5 & 0,06 & 4,03 \\
7 & Kulit Kopi & 8 & 0,59 & 3,82 \\
\hline \multicolumn{2}{r}{ Total } & 100 & 8,82 & 60,62 \\
\hline
\end{tabular}

Keterangan: TDN= Total Digestible Nutrient

Pelaksanaan penelitian diawali dengan persiapan kandang dan peralatan kadang. Selanjutnya persiapan bahan pakan dan analisis proksimat sebagai untuk mengetahui kandungan nutrien ransum kontrol. Penimbangan bobot badan awal sapi dilakukan sebagai dasar dalam menentukan pemberian ransum kontrol. Periode adaptasi dilakukan selama 7 hari. Selama periode adaptasi, sapi diberikan ransum kontrol tanpa perlakuan. Pemberian pakan dilakukan 2 kali sehari yaitu pukul 07.00 dan pukul 16.00. Pemberian air minum secara adlibitum. Sebelum dimulai periode pengambilan data dilakukan 
Prosiding Seminar Nasional Pembangunan dan Pendidikan Vokasi Pertanian Politeknik Pembangunan Pertanian Manokwari, 14 November 2020

e ISSN : 2774-1982

penimbangan bobot badan awal sapi sebagai data bobot badan awal perlakuan. Periode pengambilan data dilakukan selama 28 hari dengan pemberian pakan kontrol dan perlakuan pada masing-masing kelompok. Jumlah konsumsi bahan kering diukur setiap hari dengan cara pemberian pakan dikurangi sisa pakan dalam bahan kering. Sisa pakan dikumpulkan setiap hari kemudian diambil sampel untuk dianalisa kadar air. Bobot badan akhir sapi ditimbang pada hari ke-29. Pertambahan bobot badan harian dihitung dari bobot akhir dikurangi bobot awal pengamatan dibagi waktu perlakuan. Perhitungan konversi pakan dihitung dari jumlah pakan yang dikonsumsi (as feed) selama 28 hari dibagi pertambahan bobot badan. Data hasil penelitian diolah dengan uji $\mathrm{F}$ berdasarkan prosedur sidik ragam dan jika terdapat pengaruh perlakuan yang nyata $(\mathrm{p}<0,05)$ dilanjutkan dengan Duncan multiple range test pada taraf 5\% (Steel dan Torrie, 1995).

\section{HASIL DAN PEMBAHASAN}

Hasil penelitian menunjukkan bahwa penambahan tepung kunyit (Curcuma longa) hingga $1 \%$ bahan kering pada ransum sapi Peranakan Ongole memberikan pengaruh nyata $(\mathrm{P}<0,05)$ terhadap pertambahan bobot badan, efisiensi pakan dan feed cost pergain, namun tidak memberikan pengaruh nyata $(\mathrm{P}>0,05)$ terhadap konsumsi pakan harian. Data pengaruh penambahan tepung kunyit dalam pakan terhadap efisiensi pakan tersaji dalam tabel 2.

Tabel 2. Pengaruh Penambahan Tepung Kunyit dalam Ransum Sapi Peranakan Ongole

\begin{tabular}{lcccc}
\hline \hline \multicolumn{1}{c}{ Variabel } & P0 & P1 & P2 & Sd \\
\hline Konsumsi Pakan Harian $(\mathrm{kg})$ & 8,93 & 9,38 & 8,61 & 0,21 \\
PBB $(\mathrm{kg} / 28$ hari) & $23,60^{\mathrm{b}}$ & $23,17^{\mathrm{b}}$ & $26,13^{\mathrm{a}}$ & 0,56 \\
Efisiensi pakan $(\%)$ & $9,65^{\mathrm{b}}$ & $9,05^{\mathrm{b}}$ & $11,15^{\mathrm{a}}$ & 0,35 \\
Feed cost pergain $(\mathrm{Rp})$ & $18.360^{\mathrm{b}}$ & $22.630^{\mathrm{a}}$ & $19.690^{\mathrm{b}}$ & 793 \\
\hline
\end{tabular}

Keterangan : Superskrip yang berbeda pada baris yang sama menunjukkan pengaruh yang nyata pada taraf $5 \%(\mathrm{P}<0,05)$

Besarnya konsumsi pakan harian pada sapi Peranakan Ongole yang mendapat perlakuan penambahan tepung kunyit pada ransum menunjukkan tidak berbeda nyata (P>0,05) pada P0 yaitu sebesar 8,93 kg, P1 sebesar 9,38 kg dan P2 sebesar 8,61 kg. Hal ini diduga karena jenis dan kandungan nutrien ransum yang diberikan kepada sapi sama. Partama (2013) menyatakan bahwa beberapa yang mempengaruhi konsumsi bahan kering antara lain faktor fisiologis hewan, jenis pakan, jenis suplemen pakan yang diberikan, bobot badan ternak dan faktor lingkungan. Kandungan kurkumin dan atsiri pada kunyit yang ditambahkan belum berpengaruh terhadap peningkatan nafsu makan sapi. Penambahan tepung kunyit hingga dosis $0,2 \%$ dari bahan kering ransum sapi potong 
Prosiding Seminar Nasional Pembangunan dan Pendidikan Vokasi Pertanian

Politeknik Pembangunan Pertanian Manokwari, 14 November 2020

e ISSN : 2774-1982

belum memberikan pengaruh nyata terhadap konsumsi bahan kering, organik, lemak kasar, dan serat kasar namun dapat meningkatkan retensi protein dan menurunkan kecernaan serat (Vorlaphim et al., 2011).

Besarnya Pertambahan bobot badan sapi selama 28 hari yang mendapat perlakuan $\mathrm{P} 2$ nyata lebih tinggi $(\mathrm{P}<0,05)$ yaitu sebesar $26,13 \mathrm{~kg}$ daripada $\mathrm{P} 0$ sebesar 23,60 kg dan P1 sebesar 23,17 kg. Besarnya P0 dan P1 tidak berbeda nyata. Hal ini diduga karena kecernaan pakan pada sapi yang mendapat perlakuan P2 lebih tinggi daripada P0 dan P1 sehingga nutrien yang terserap lebih tingi dan menyebabkan pertambahan bobot badan yang lebih tinggi. Kandungan kurkumin dan atsiri yang terkandung dalam kunyit dapat meningkatkan kecernaan nutrien di dalam saluran pencernaan. Li et al., (2011) menyatakan bahwa kandungan kurkumin dan atsiri dalam tepung kunyit juga berfungsi sebagai antiprotozoa yang dapat menekan jumlah protozoa di dalam rumen sehingga dapat meningkatkan kecernaan nutrien pakan di dalam rumen. Hasil penelitian Prasetiadi et al., (2017) menyatakan bahwa penambahan tepung kunyit $0,5 \%$ dari bahan kering ransum domba jantan lokal cenderung menghasilkan pertambahan bobot badan paling baik daripada penambahan tepung kunyit pada dosis $0,75 \%, 1 \%$ dan tanpa pemberian tepung kunyit, namun belum memberikan pengaruh nyata terhadap konversi pakan domba.

Efisiensi pakan sapi yang mendapatkan perlakuan P2 (11,15\%) nyata lebih tinggi $(\mathrm{P}<0,05)$ daripada sapi P0 $(9,65 \%)$ dan P1 $(9,05 \%)$. Hal ini dipengaruhi oleh besarnya pertambahan bobot badan P2 yang nyata lebih tinggi daripada P0 dan P1 dan besarnya konsumsi ransum pakan harian yang sama antar perlakuan. Nilai efisiensi penggunaan pakan yang semakin tinggi menunjukkan bahwa jumlah ransum yang dikonsumsi semakin sedikit untuk menghasilkan $1 \mathrm{~kg}$ bobot badan. Nurhayu et al. (2011) menyatakan bahwa pakan yang diberikan pada ternak dikatakan efisien apabila pakan tersebut dapat dikonsumsi sepenuhnya oleh ternak dan tercerna dengan baik pula.

Nilai feed cost pergain sapi yang mendapatkan perlakuan P1 (Rp. 22.630) nyata lebih tinggi $(\mathrm{P}<0,05)$ daripada P2 (Rp. 19.690,-) dan P0 (Rp. 18.360,-). Besarnya feed cost pergain P2 dan P0 tidak berbeda nyata. Hal ini berarti untuk mendapatkan $1 \mathrm{~kg}$ bobot badan sapi yang mendapatkan P1 menggunakan biaya pakan lebih tinggi daripada P0 dan $\mathrm{P} 2$. Meskipun ransum yang diberikan sama, namun penambahan tepung kunyit sebagai feed aditif membuat harga pakan P1 yaitu sebesar Rp. 2.000,- dan P2 Rp. 2.150,- menjadi lebih tinggi daripada ransum P0 sebesar Rp. 1.850,-. Namun ternyata dengan konsumsi ketiga perlakuan yang sama, pertambahan bobot badan P2 nyata lebih tinggi daripada P1 
Prosiding Seminar Nasional Pembangunan dan Pendidikan Vokasi Pertanian

Politeknik Pembangunan Pertanian Manokwari, 14 November 2020

e ISSN : 2774-1982

dan P0 sehingga membuat nilai feed cost pergain P2 paling rendah. Muyasaroh et al., (2015) menyatakan bahwa biaya pakan yang murah belum tentu menghasilkan feed cost pergain yang rendah.

\section{KESIMPULAN DAN SARAN}

Kesimpulan dari hasil penelitian menunjukkan bahwa penambahan tepung kunyit hingga $1 \%$ bahan kering pada ransum sapi Peranakan Ongole menunjukkan pengaruh positif terhadap pertambahan bobot badan, efisiensi pakan dan feed cost pergain, meskipun tidak menujukkan pengaruh nyata terhadap konsumsi pakan harian. Penambahan tepung kunyit sebanyak $1 \%$ menunjukkan level terbaik terhadap pertambahan bobot badan, efisiensi pakan dan feed cost pergain pada sapi.

\section{UCAPAN TERIMA KASIH}

Ucapan terimakasih diberirikan kepada DRPM Kementerian Riset dan Teknologi/Badan Riset dan Inovasi Nasional yang telah membiayai penelitian skema Penelitian Dosen Pemula Tahun Anggaran 2020. Serta ucapan terimakasih kepada Bapak Ponijo selaku pemilik Peternakan Sapi Joe Cipir Desa Jati Indah, Kecamatan Tanjung Bintang, Kabupaten Lampung Selatan yang telah memberikan fasilitas untuk melaksanakan penelitian di peternakan tersebut.

\section{DAFTAR PUSTAKA}

Budiari, N. L. G., Y. Pujiawati., I. N. Adijaya \& I. P. A. Kertawirawan. (2020). Pengaruh Level Tepung Kunyit Pada Ransum Sapi Bali Terhadap Performans dan Pendapatan Peternak. Di dalam: Prospek Peternakan di Era Normal Baru Pasca Pandemi COVID-19. Prosiding Seminar Teknologi dan Agribisnis Peternakan VII-Webinar. 27 Juni 2020. Purwokerto. Fakultas Peternakan Jenderal Soedirman. 618-627.

Direktorat Jenderal Peternakan dan Kesehatan Hewan Kementerian Pertanian. (2018). Statistik Peternakan dan Kesehatan Hewan 2018. Direktorat Jenderal Peternakan dan Kesehatan Hewan Kementerian Pertanian, Jakarta.

Hartati, S. Y. (2013). Khasiat Kunyit Sebagai Obat Tradisional dan Manfaat Lainnya. Warta Penelitian dan Pengembangan Tanaman Industri. 19 (2): 5-9.

Menteri Pertanian Republik Indonesia. (2012). Keputusan Menteri Pertanian No 2841/Kpts/LB.430/8/2012 Tentang Penetapan Rumpun Sapi Peranakan Ongole. Jakarta.

Nurhayu. A., M. Sariubang, Nasrullah \& A. Ella. (2011). Respon Pemberian Pakan Lokal terhadap Produktivitas Sapi Bali Dara di Kabupaten Bantaeng, Sulawesi Selatan. Seminar Nasional Teknologi Peternakan dan Veteriner. Bogor 
Li, M., W. Yuan., G. Deng., P. Wang., P. Yang \& B. B. Anggarwal. (2011). Chemical Composition and Product Quality Control of Turmeric (Curcuma longa). Pharmaceutical Crops, 2: 28-54.

Muyasaroh, S., I. G. S. Budisatria \& Kustantinah. (2015). Income Feed Over Cost Penggemukan Sapi Oleh Kelompok Sarjana Membangun Desa (SMD) di Kabupaten Bantul dan Sleman. Buletin Peternakan. 39(3): 205-211.

Partama, I. B. G. (2013). Nutrisi dan Pakan Ruminansia. Udayana University Press, Denpasar.

Prasetiadi, R. , D. Heriyadi \& Y. Yurmiati. (2017). Performa Domba Lokal Jantan Yang Diberikan Tambahan Tepung Kunyit (Curcuma Domestica Val.). Jurnal Ilmu Ternak. 17(1) : 54-57.

Shan, C. Y., \& Y. Iskandar. (2018). Studi Kandungan Kimia Dan Aktivitas Farmakologi Tanaman Kunyit (Curcuma longa L.). Farmaka Suplemen. 16 (2): 548-553.

Vorlaphim, T., M. Phonvisay., J. Khotsakdee., K. Vasupen., S. Bureenok., S. Wongsuthavas., A. Alhaidary., H. E. Mohamed., A. C. Beynen \& C. Yuangklang. (2011). Influence of Dietary Curcumin on Rumen Fermentation, Macronutrient Digestion and Nitrogen Balance in Beef Cattle. American Journal of Agricultural and Biological Sciences 6(1):7-11.

Wati, N. E. \& M. Yusuf. (2019). Peningkatan Produktivitas Sapi Peranakan Simmental dengan Penambahan Tepung Temulawak (Curcuma xanthorhiza) sebagai Pakan Aditif Alami. Di dalam: Teknologi Peternakan dan Veteriner Mendukung Kemandirian Pangan di Era Industri 4.0. Prosising Seminar Nasional Teknologi Peternakandan Veteriner 2019. 15-16 Oktober 2019. Jember. Pusat Penelitian dan Pengembangan Peternakan, Kementerian Pertanian. 165-170.

Wati, N. E. \& M. Yusuf. (2020). Pengaruh Penambahan Tepung Temulawak (Curcuma xanthoriza) dalam Ransum Terhadap Efisiensi Pakan Sapi Peranakan Simmental. Wahana Peternakan. 4(1): 1-5.

Steel, R.G.D. \& J.H. Torrie. (1995). Prinsip dan Prosedur Statistika Suatu Pendekatan Biometrik. Cetakan ke-4. PT. Gramedia Pustaka Utama, Jakarta. (Diterjemahkan Oleh B. Sumantri). 